1-1-1939

\title{
The relative merits of producing creep-fed, feeder, and lot-fattened calves in West Virginia
}

\author{
C. V.Wilson \\ E.W.McComas
}

Follow this and additional works at: https://researchrepository.wvu.edu/ wv_agricultural_and_forestry_experiment_station_bulletins

\section{Digital Commons Citation}

Wilson, C. V. and McComas, E. W., "The relative merits of producing creep-fed, feeder, and lot-fattened calves in West Virginia" (1939). West Virginia Agricultural and Forestry Experiment Station Bulletins. 295.

https://researchrepository.wvu.edu/wv_agricultural_and_forestry_experiment_station_bulletins/296 @ WVU. It has been accepted for inclusion in West Virginia Agricultural and Forestry Experiment Station Bulletins by an authorized administrator of The Research Repository @WVU. For more information, please contact ian.harmon@mail.wvu.edu. 

The Relative Merits of Producing Creep-Fed, Feeder, and Lot-Fattened Calves In West Virginia

\author{
by C. V. Wilson and E. W. MeComas
}

\title{
LIBRARY \\ WEST VIRGINIA UNIVERSITY
}

\section{West Virginia Agricultural Experiment Station}

C. R. Orton, Director, Morgantown

In cooperation with the Bureau of Animal Industry

United States Department of Agriculture 


\section{The Relative Merits of Producing Creep-Fed, Feeder, And Lot-Fattened Calves in the Appalachian Region ${ }^{1}$}

By C. V. Wilson, associate animal husbandman, West Virginia Agricultural

Experiment Station, and E. W. McComas, animal husbandman,

Animal Husbandry Division, Bureau of Animal Industry,

United States Department of Agriculture.

\section{INTRODUCTION}

The Appalachian region has supported a large number of small herds of beef.cattle for several generations and has long been recognized as a source of feeder cattle and grass-fat cattle, the latter attaining sufficient finish on pasture alone to meet market-beef requireinents.

The results of previous experiments pointed the way toward economical methods of wintering breeding herds and steers of different ages. ${ }^{3}$ Later studies indicated methods for shortening the time required to produce cattle fat enough to meet market requirements by feeding a grain supplement while they were on pasture. ${ }^{4}$

Experiments in the Corn Belt in recent years have shown that wellfinished steers can be produced at weaning time or shortly thereafter by creep-feeding. The results in that region made it appear advisable to determine the adaptability of this method to the farms in the Appalachian region, the pastures and cropland of which compare favorably with those of the Corn Belt, and to the farms with highquality pastures but with limited cropland, yet so situated that grain can be procured readily.

The present experiments were made to determine the relative merits of producing (1) fat weanling calves on highly productive land by creep-feeding of supplements, (2) fat calves by pasturing them with their dams on highly productive land and lot-feeding them after weaning, and (3) feeder calves either on highly productive land or on less fertile, rough, mountainous land in the Appalachian region. The work was carried on in the bluegrass section of West Virginia near Lewisburg, with calves born in 1933, 1934, and 1935.

\section{EXPERIMENTAL PROCEDURE}

\section{CATTLE. LAND, AND EQUIPMENT USED}

Sixty grade Hereford beef cows $21 / 2$ to 6 years old obtained in southeastern West Virginia were divided into two groups on the basis of conformation, age, breeding, and weight and bred to two highquality registered Hereford bulls similar in age, breeding, and con-

\footnotetext{
${ }^{1}$ Reprinted from Tech. BuI. 664, U.S.D.A. November 1938.

2 'The experments were directed by W. H. Black, senior animal husbandman, Anlmal Hushandry Division. Bureau of Animai Industry, U. S. Department of Agriculture, and E. A. Livesay, head of the Department of Animal Husbandry, West Virginia Agricultural Experiment Station.

${ }^{3}$ Blark, W. II. Wintering BFfF cattle in the appalachian region. U. S. Dept. Agr. Dept. Cir. 408,12 pp., illus. 1927.

BLACK, W. li., WARNER, K. F., and WILSON, C. V. BEEF PRODUCTION AND QUALITY AS AFFECTED BY GRADE OF STEER AND FEEDING GRAIN SUPPLEMENT ON GRASS. U. S. Dept. Agr. 'Tech. Bull. 217, 44 pp., illus. 1931.

and others. BEGF PRODUCTION AND QUALITY AS AFFECTED BY METHOD OF FEEDING GRAIN SUPPLEMIENTARY TO GRASS. [Unpublished manuscript.]
} 
formation. Heifers selected from the calf crop before the calves were marketed were used as replacements for cows that died or that were removed from the experiments because of disease or injury.

Two types of bluegrass pasture land were used in these experiments. One consisted of rolling, hilly, but fertile land with no timber; the other of rough, mountainous, sparsely wooded land of several hundred feet greater elevation. The carrying capacity of these two pastures was estimated to be 4 and 8 acres, respectively, for one cow and calf. Each pasture afforded adequate shade and water during the grazing season. Barns adjacent to the pastures were used for feeding and shelter in winter, but the cattle were not confined during this season.

A creep was set up in the pasture used by the group $1 \mathrm{~A}$ cows and their calves. Stock scales were located in both pastures.

\section{FEEDING AND HANDLING OF THE CATTLE}

The experiments were begun in May 1932 at the commencement of the breeding season and continued until March 1936 with the lotfattened calves. The cows comprising group 1 were turned into the lower pasture and those in group 2 into the mountain pasture about April 26 of each year. The bulls were turned into the pastures with the cows about May 11 and allowed to run with them for 70 days, after which they were removed and pastured at some distance from the cows. The two bulls were alternated annually between the two cow herds.

Corn silage, cottonseed meal, and wheat straw were the winter feeds for the group 1 cows and both bulls. Mixed hay alone was fed to the group 2 cows the first winter but as it appeared to be inadequate, subsequently a small quantity of shelled yellow corn was fed in order that the cows which calved early would be somewhat more vigorous at calving time.

About May 25 of each year, the cows and calves in the group 1 herd were divided as equally as possible into groups $1 \mathrm{~A}$ and $1 \mathrm{~B}$. They were assigned to the two groups on the basis of the age, weight, conformation, and quality of the calves. Each group was limited to one-half of the lower pasture during the remainder of the grazing season. During this time the bull was kept one-half of each day with each group.

Group $1 \mathrm{~A}$ calves had access in a creep to a feed mixture of 8 parts of shelled yellow corn and 1 part of cottonseed meal by weight for 168 days beginning about May 25 of each year. A small quantity of oats was fed at the beginning of the first year to induce the group $1 \mathrm{~A}$ calves to eat grain more readily, but this feed was not necessary in succeeding years. Neither the group $1 \mathrm{~B}$ calves, raised on the highly productive pasture land, nor the group 2 calves, raised on the less fertile mountain pasture, received any supplement from about May 25 of each year until about November 10. Common salt was available to the calves, as well as to the cows, at all times.

All feeds except the mixture given to the creep-fed calves were weighed at each feeding and the quantity was recorded. Only a small 
quantity of feed was refused during these experiments, but any that remained in the bunks or racks at the time of the next feeding was removed, weighed, and recorded. The mixture for the creep-fed calves was weighed before it was put into the self-feeder and that which remained at the end of the experiment was weighed back. When the record of an individual cow or calf had to be omitted as the result of death or injury of the animal or other cause, the quantity of feed to be deducted from the total fed to the group was determined on the basis of the ratio of the live weight of the animal to the total weight of animals in the group during the time it was in the experiment.

At the end of a 168-day grazing period all calves were weaned. They were weighed individually on 3 consecutive days at the beginning and end of the experiments, and the average of the three weights was taken as the initial and final weights. They were also weighed at regular 28-day intervals. When the calves were weaned, a committee representing the United States Department of Agriculture and the West Virginia Agricultural Experiment Station graded the calves in group $1 \mathrm{~A}$ as slaughter calves and those in groups $1 \mathrm{~B}$ and 2 as feeders. The committee appraised the value of the feeders at the station. The group $1 \mathrm{~A}$ calves were then driven to the railroad loading point about 4 miles from the station and shipped to Baltimore, Md. Here they were graded by the committee before they were sold.

The calves in group $1 \mathrm{~B}$ were put in the feed lot about November 9 and fed the shelled-corn and cottonseed-meal mixture and alfalfa hay until they had attained what was believed to be the same degree of fatness as that displayed by the group $1 \mathrm{~A}$ calves at weaning time. They were marketed each year at Baltimore.

The experimental work with the group 2 calves ended at the time they were weaned and appraised as feeders.

\section{FEEDS USED AND THEIR VALUES}

All corn fed during the experiments was of No, 2 grade coarsely ground, and 41-percent cottonseed meal was used.

The alfalfa hay and most of the mixed hay (consisting of clover and timothy) were produced on the farm. Although not officially graded, these hays were comparable with the No. 2 standard, for they were well cured, fairly leafy, free from weeds, and had a moderately bright-green color.

TABLE 1.-Values of feeds used during the experiments ${ }^{1}$

\begin{tabular}{|c|c|c|c|c|}
\hline Feed & 1932-33 & $1933-34$ & 1934-35 & 1935-36 \\
\hline Corn, shelled, 2 per bushel - & & $\$ 0.50$ & $\$ 0.84$ & $\$ 0.70$ \\
\hline $\begin{array}{l}\text { Corn, shelled, }{ }^{3} \text { per bushel } \\
\text { Cottonseed nieal, }{ }^{2} \text { per ten.... }\end{array}$ & & 20.00 & 30.00 & 30.00 \\
\hline Cottonseed meal,3 per ton..... & $\$ 20$ & 20.00 & 40.00 & 30.00 \\
\hline Corn silage, per ton........ & 4 & 4. 00 & 6.00 & $\begin{array}{r}6.00 \\
20.00\end{array}$ \\
\hline Alfalfa hay, per ton & 10 & 10.00 & 15. 00 & 15. 00 \\
\hline $\begin{array}{l}\text { Mixed hay, per ton } \\
\text { Wheat straw, per ton }\end{array}$ & 4 & 4.00 & 4.00 & 4.00 \\
\hline
\end{tabular}

1 Pasturage for 1 cow and calf was valued at 5 cents per day.

2 Purchased for creep-feeding.

3 Purchased for wintering cows and fattening group $1 \mathrm{~B}$ calves. 
The corn used for silage was also grown on the farm and was of good quality. The wheat straw was of good quality, clean, and bright, and was obtained locally.

The values of the feeds used are shown in table 1.

\section{WEATHER CONDITIONS DURING THE EXPERIMENTS}

The summers of 1932,1933 , and 1935 and the winters of 1932-33 and 1933-34 were nearly normal or average for the region. During the early part of the 1934 grazing season, however, the rainfall was somewhat deficient, but late in the summer and early in the fall there was enough rainfall to assure adequate pasturage at the station. The early part of the winter of 1934-35 was mild, but the weather during part of February 1935 was exceptionally severe. The first 3 months of the winter of 1935-36 were more severe than were those of either of the 2 preceding years.

\section{EXPERIMENTAL RESULTS}

\section{GAINS OR LOSSES IN WEIGHT AND FEED DATA OF DAMS}

The average winter losses in weight and feed data of the dams are shown in table 2. The losses per head of the two groups of cows over the 3-year period were practically the same. The great variation in the average loss of the group- 2 cows in the different years is due partly to difference in the time of calving and partly to difference in percentage of calf crop.

TABLE 2.-Average winter loss in weight, feed consumption, and feed cost per cow by groups and years

\begin{tabular}{|c|c|c|c|c|c|c|c|c|c|c|}
\hline \multirow[b]{2}{*}{ Group } & \multirow[b]{2}{*}{$\begin{array}{l}\text { Year of ex- } \\
\text { periment }\end{array}$} & \multirow[b]{2}{*}{ Cows } & \multirow[b]{2}{*}{$\begin{array}{c}\text { Days } \\
\text { fed }\end{array}$} & \multirow[b]{2}{*}{$\begin{array}{l}\text { Loss in } \\
\text { weight }\end{array}$} & \multicolumn{5}{|c|}{ Total consumption of- } & \multirow{2}{*}{$\begin{array}{l}\text { Total } \\
\text { feed } \\
\text { cost }\end{array}$} \\
\hline & & & & & $\begin{array}{l}\text { Corn } \\
\text { silage }\end{array}$ & $\begin{array}{l}\text { Wheat } \\
\text { straw }\end{array}$ & $\begin{array}{l}\text { Cotton- } \\
\text { seed- } \\
\text { meal }\end{array}$ & $\begin{array}{c}\text { Mixed } \\
\text { hay }\end{array}$ & $\begin{array}{c}\text { Shelled } \\
\text { corn }\end{array}$ & \\
\hline \multirow[t]{2}{*}{$\begin{array}{l}\text { 1, fed silage, straw, } \\
\text { and cottonseed } \\
\text { meal. }\end{array}$} & $\left\{\begin{array}{l}1932-33 \ldots \\
1933-34 \ldots \\
1934-35 \ldots\end{array}\right.$ & $\begin{array}{c}\text { Num- } \\
\text { ber } \\
30 \\
29 \\
23\end{array}$ & $\begin{array}{c}\text { Num- } \\
\text { ber } \\
147 \\
140 \\
140\end{array}$ & $\begin{array}{r}\text { Pounds } \\
149 \\
167 \\
164\end{array}$ & $\begin{array}{l}\text { Pounds } \\
2,886 \\
2,838 \\
2,799\end{array}$ & $\begin{array}{r}\text { Pounds } \\
930 \\
966 \\
1,000 \\
\end{array}$ & $\begin{array}{c}\text { Pounds } \\
143 \\
145 \\
140\end{array}$ & \begin{tabular}{l} 
Pounds \\
\hdashline
\end{tabular} & 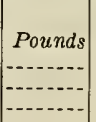 & $\begin{array}{l}\text { Dols. } \\
9.16 \\
13.35 \\
13.20\end{array}$ \\
\hline & A verage. & & 142 & 160 & 2,842 & 982 & 143 & ......... & ........ & 11.86 \\
\hline \multirow[t]{2}{*}{$\begin{array}{l}\text { 2, fed mixed hay } \\
\text { alone or } \\
\text { shelled corn. }\end{array}$} & $\left\{\begin{array}{l}1932-33-\ldots \\
1933-44 \ldots \\
1934-35 \ldots\end{array}\right.$ & $\begin{array}{l}29 \\
28 \\
27\end{array}$ & $\begin{array}{l}147 \\
140 \\
140\end{array}$ & $\begin{array}{r}138 \\
78 \\
257\end{array}$ & & & & $\begin{array}{l}2,110 \\
2,031 \\
2,221\end{array}$ & $\begin{array}{l}160 \\
141\end{array}$ & $\begin{array}{l}10.55 \\
16.38 \\
18.91\end{array}$ \\
\hline & A verage. & & 142 & 156 & & & & 2,118 & ${ }^{1} 151$ & 15. 19 \\
\hline
\end{tabular}

1 A verage for 2 years.

The average cost, per head, of the winter feed consumed by the group 2 cows was about 28 percent greater than that by the cows in group 1. In the first year the cows in group 2 wintered satisfactorily on mixed hay but did not do so well for several weeks after calving as did the cows in group 1 . Hence a small quantity of shelled corn was added to the ration during the second and third winters. 
The data in table 3 show that during the first year the average summer gain of the cows whose calves were creep-fed (group 1A) was nearly 23 percent greater than that of the cows whose calves received no grain supplement on good pasture (group 1B) and nearly 26 percent greater than the gain of the cows on the lower quality mountain pasture (group 2). In the second year, however, cows in group 1A gained only 7.6 percent more than those in group $1 \mathrm{~B}$ and 5.6 percent more than the group- 2 cows. In the third year the gain of group 1A was only 0.8 percent greater than that of group $1 \mathrm{~B}$ but was 11.4 percent more than that of group 2. In the 3 years the cows in group 1A gained 10.6 percent more than those in group $1 \mathrm{~B}$ and 133 percent more than those in group 2. The cows in all three groups gained satisfactorily during the suckling period each year.

TABLE 3.-Average initial weight and gain per dam during the suckling period each year

\begin{tabular}{|c|c|c|c|c|}
\hline Group No. & Period & Dams & $\begin{array}{l}\text { Initial } \\
\text { weight }\end{array}$ & $\begin{array}{l}\text { Qain in } \\
\text { weight }\end{array}$ \\
\hline \multirow[t]{2}{*}{$\begin{array}{l}\text { 1A (dams of creep-fed calves on good } \\
\text { pasture). }\end{array}$} & \multirow{4}{*}{ 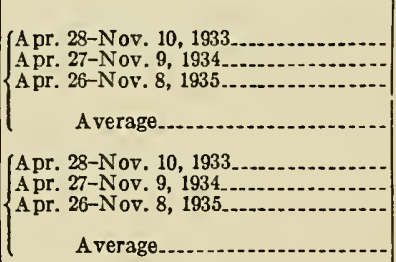 } & \multirow{2}{*}{$\begin{array}{r}\text { Number } \\
14 \\
11 \\
11\end{array}$} & $\begin{array}{r}\text { Pounds } \\
823 \\
870 \\
890\end{array}$ & $\begin{array}{r}\text { Pounds } \\
239 \\
226 \\
254\end{array}$ \\
\hline & & & 859 & 239 \\
\hline \multirow[t]{2}{*}{$\begin{array}{l}\text { IB (dams of calves recelving no sup- } \\
\text { plement on good pasture). }\end{array}$} & & \multirow[t]{2}{*}{$\begin{array}{l}15 \\
11 \\
11\end{array}$} & $\begin{array}{l}810 \\
844 \\
900\end{array}$ & $\begin{array}{l}194 \\
210 \\
252\end{array}$ \\
\hline & & & 847 & 216 \\
\hline \multirow[t]{2}{*}{2 (dams on mountain pasture) } & \multirow{2}{*}{ 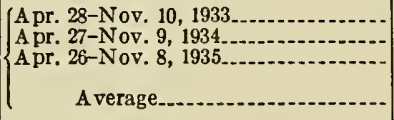 } & \multirow[t]{2}{*}{$\begin{array}{l}23 \\
14 \\
25\end{array}$} & $\begin{array}{l}804 \\
849 \\
864\end{array}$ & $\begin{array}{l}189 \\
214 \\
228\end{array}$ \\
\hline & & & 838 & 211 \\
\hline
\end{tabular}

\section{RESULTS FROM THREE GROUPS OF CALVES AT END OF SUCKLING PERIOD}

TOTAL WEIGHTS, GAINS, AND FEED DATA

Table 4 summarizes the results obtained from the three groups of calves during the suckling period.

The differences in the average initial weights per calf in the three groups were not significant.

The variation in the average gain of the creep-fed calves (group 1A) was substantially the same as that of the calves not creep-fed (group 1B and group 2) during the suckling period. However, a comparison of the average data for the 3 years shows that the group $1 \mathrm{~A}$ calves gained 27 pounds, or 8.1 percent, a head more than the group $1 \mathrm{~B}$ calves and 73 pounds, or 25.3 percent, more than the group 2 calves. The differences in final weight are significantly in favor of the group 1A calves. This group consistently showed a distinctly higher degree of finish at weaning time than did the other groups, 
a fact that was supported by the findings of the grading committee. All the calves in group $1 \mathrm{~A}$ were classed as slaughter cattle, whereas all the others were classed as feeders.

The table shows that there was a progressive reduction in the average quantity of supplemental feed consumed per head cach year by the group $1 \mathrm{~A}$ calves even though the mixture was available at all times during the 168-day period. Markedly lower feed prices in 1933 than in 1934 and 1935 account for the lower value of the feed consumed per steer in 1933 than in the other 2 years.

\section{COMPARATIVE RETURNS FROM CALVES}

The return per calf in group $1 \mathrm{~B}$ at weaning was larger than that in groups $1 \mathrm{~A}$ and 2 in 1934 and 1935 and also when the 3 years' data were averaged. However, the returns from group 1A are not exactly comparable with those from groups $1 \mathrm{~B}$ and 2. Marketing charges of $\$ 3.71$ per calf were deducted from the returns of the firsi-mentioned group, whereas this deduction was not made from the returns of the other groups, since they were not shipped to market at this time. However, even after marketing charges were deducted in the case of group 1A, their returns were still considerably higher than those of the group 2 calves raised on the less fertile, more mountainous land. In 2 of the 3 years the latter group did not yield sufficient returns to offset the value of pasture and their dams' feed. In the third year the returns were especially favorable. If the $1 \mathrm{~B}$ calves had been sent to market at this time, their returns would also have been lower than those of group $1 \mathrm{~A}$.

Attention is called to the fact that the price of fat cattle was relatively somewhat lower than that of Choice feeder calves in the fall of 1933 and of 1934, although both were distinctly lower than in the corresponding period in 1935 . The feeder calves were appraised on a basis of current market prices for calves of similar grade and quality, but the values given for the fat calves are the prices actually paid for them at the market.

\section{DALY QUANTITIES OF SUPPLEMENTS AND DAILY GAINS}

Table 5 shows the daily quantities of supplements received by animals in group $1 \mathrm{~A}$ and the daily gairs of the three groups of calves by 28 -day periods before the animals were weaned. Neariy 2 months was required each year to induce the calves to eat appreciable quantities of supplement in the creep. At the beginning of the first year a very small quantity of oats was fed to hasten the consumption of the feed mixture, but this procedure was not repeated in the two subsequent years.

The creep-fed calves (group 1A) gained a little more rapidly than the others during the last three 28-day periods each year and averaged a slightly higher gain during all periods except the first. An average consumption of 2.65 pounds of the supplement per head daily apparently accounted for the difference in development at weaning time, as well as the slightly greater gain during the 168-day period. 


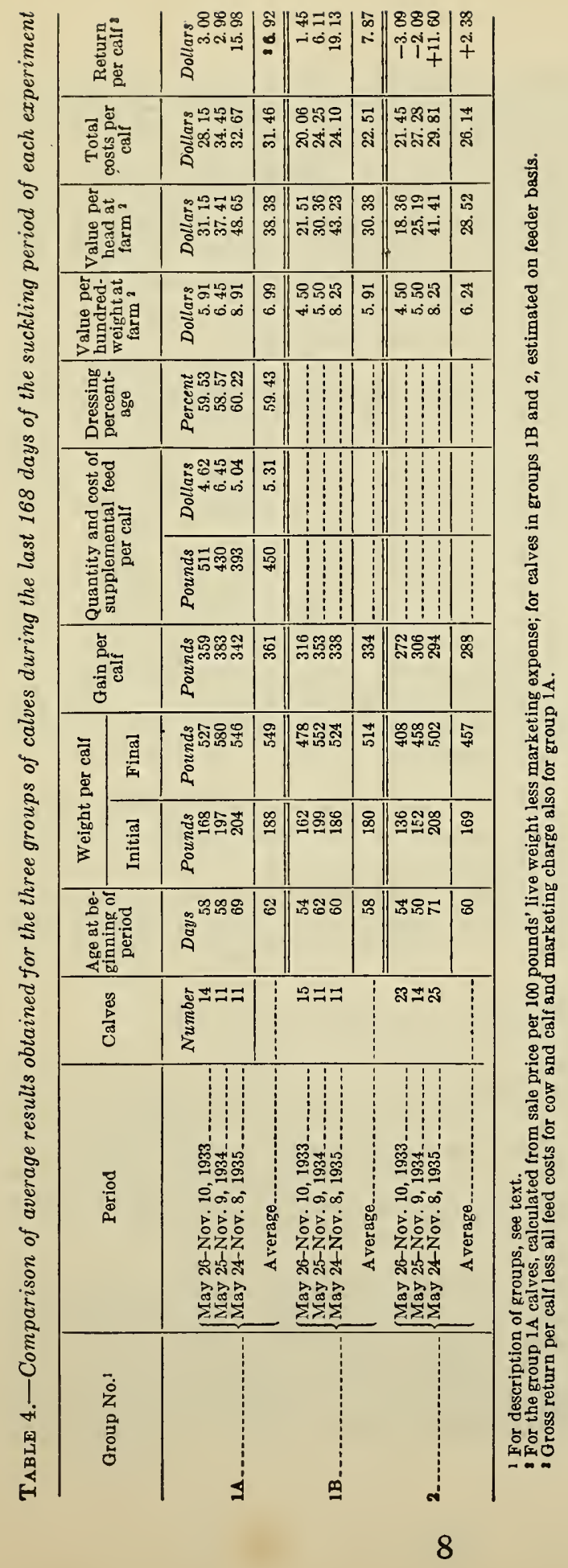


The creep-fed calves were fat, whereas those in groups $1 \mathrm{~B}$ and 2 were merely in good flesh.

TABL木 5.-Feed mixture consumed by calves in group $1 A$ and daily gains of the three groups of calves by 28 -day periods prior to weaning

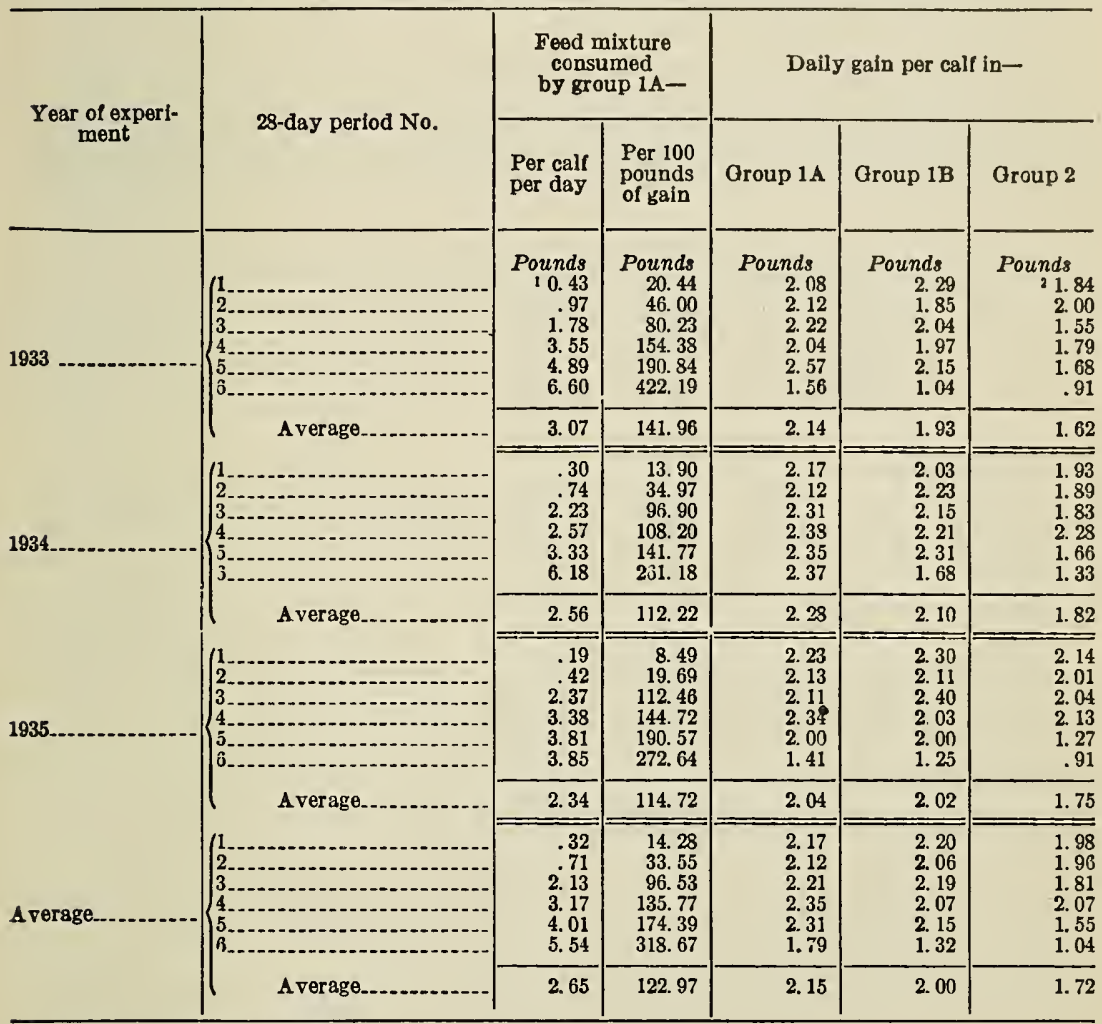

\footnotetext{
10.054 pound of oats included.
}

1 A verage of 22 head instead of 23.

Table 5 shows a gradual increase in daily consumption of the supplement by the creep-fed calves during the first five periods and a much greater increase during the sixth period of the first two experiments. This rapid increase was very likely occasioned by a marked change in diet involving a decrease in the supply of nutrients from grass and milk. The relatively small quantity of feed mixture consumed in the sixth period of the 1935 experiment, as compared with the consumption during the same period in the other years, was probably due to more abundant pasturage toward the end of the year. All three groups of calves, except those that were creep-fed in the second year gained less during this sixth period than in several of the preceding ones. An important point in the creep-feeding method of fattening calves for beef is the relatively small quantity of supplement required to produce 100 pounds of gain. In a previous experi- 
ment at this station, 3-year-old steers, grading Good, when fed a grain supplement for 125 days while on pasture, required 176 pounds more supplement for each 100 pounds of gain than did the steer calves in the present experiment, as calculated from the data of Black, Warner, and Wilson.

\section{RESULTS FROM GROUP OF CALVES FATTENED IN DRY LOT AFTER WEANING}

Table 6 shows that at the beginning of the fattening period in 1933 the group $1 \mathrm{~B}$ calves, receiving no supplement during the suckling period and fattened in the dry lot, averaged 72 pounds less in weight TABLE 6.-Average results obtained from the group $1 B$ calves from weaning to marketing (calves fattened in dry lot after weaning)

\begin{tabular}{|c|c|c|c|c|c|c|c|c|c|c|}
\hline \multirow[b]{2}{*}{ Period } & \multirow{2}{*}{$\begin{array}{c}\text { Length } \\
\text { of } \\
\text { feeding } \\
\text { period }\end{array}$} & \multirow{2}{*}{ Calves } & \multicolumn{2}{|c|}{ Weight per calf } & \multirow{2}{*}{$\begin{array}{l}\text { Gain } \\
\text { per } \\
\text { calf }\end{array}$} & \multirow{2}{*}{$\begin{array}{c}\text { Dres- } \\
\text { sing } \\
\text { per- } \\
\text { centage }\end{array}$} & \multirow{2}{*}{$\mid \begin{array}{c}\text { Value } \\
\text { per } \\
\text { hun- } \\
\text { dred- } \\
\text { weight } \\
\text { at farm } 1\end{array}$} & \multirow{2}{*}{$\begin{array}{c}\text { Value } \\
\text { per } \\
\text { head } \\
\text { at } \\
\text { farm }\end{array}$} & \multirow{2}{*}{$\begin{array}{l}\text { Total } \\
\text { cost } \\
\text { per } \\
\text { calf }\end{array}$} & \multirow{2}{*}{$\begin{array}{l}\text { Return } \\
\text { per } \\
\text { calf? }\end{array}$} \\
\hline & & & Initial & Final & & & & & & \\
\hline $\begin{array}{l}\text { Nov } 10,1933-M a r . \\
2,1934\end{array}$ & $\begin{array}{c}\text { Days } \\
112\end{array}$ & $\begin{array}{c}\text { Num- } \\
\text { ber } \\
{ }_{13}\end{array}$ & $\begin{array}{c}\text { Pounds } \\
478\end{array}$ & $\begin{array}{c}\text { Pounds } \\
615\end{array}$ & $\begin{array}{c}\text { Pounds } \\
137\end{array}$ & $\begin{array}{c}\text { Percent } \\
57.96\end{array}$ & $\begin{array}{r}\text { Dollars } \\
6.26\end{array}$ & $\begin{array}{c}\text { Dollars } \\
38.50\end{array}$ & $\begin{array}{c}\text { Dollars } \\
35.09\end{array}$ & $\begin{array}{r}\text { Dollars } \\
3.41\end{array}$ \\
\hline $\begin{array}{l}\text { Nov, 9, } 1934-\text { Mar. } \\
1,1935 .\end{array}$ & 112 & 9 & 550 & 682 & 132 & 59. 17 & 8.65 & 58.99 & 50.58 & 8.41 \\
\hline $\begin{array}{l}\text { Nov, } 8,1935-M a r . \\
\text { 14, } 1936 \text {. }\end{array}$ & 127 & 9 & 517 & 647 & 130 & 58. 13 & 8. 18 & 52.92 & 44. 52 & 8.40 \\
\hline A verage & 116 & & 510 & 644 & 134 & 58.38 & 7. 51 & 48. 36 & 42.32 & 6.04 \\
\hline
\end{tabular}

1 Calculated from sale price per 100 pounds live weight less marketing charges.

2 Gross return per calf less all feed costs for cow and calf and marketing charge per calf.

TABLE 7.-Average rations and daily gains of group $1 B$ calves by $2 S$-day periods in the dry lot after weaning

\begin{tabular}{|c|c|c|c|c|}
\hline \multirow[b]{2}{*}{ Year of experiment } & \multirow{2}{*}{$\begin{array}{l}\text { Period } \\
\text { No. }\end{array}$} & \multicolumn{2}{|c|}{ Ration } & \multirow[b]{2}{*}{ Daily gain } \\
\hline & & $\begin{array}{c}\text { Feed mix- } \\
\text { ture }\end{array}$ & Hay & \\
\hline $1933-34 \ldots$ & $\left\{\begin{array}{l}1, \ldots \\
3 \\
3 \\
4\end{array}\right.$ & $\begin{array}{r}\text { Pounds } \\
6.18 \\
7.85 \\
9.38 \\
10.90\end{array}$ & $\begin{array}{r}\text { Pounds } \\
4.12 \\
2.85 \\
2.85 \\
3.48\end{array}$ & $\begin{array}{r}\text { Pounds } \\
0.31 \\
1.50 \\
1.76 \\
1.33\end{array}$ \\
\hline A verage.... & & 8.58 & 3.33 & $\overline{1.22}$ \\
\hline $1934-35 \ldots . .$. & 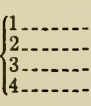 & $\begin{array}{l}5.17 \\
7.98 \\
8.00 \\
9.66\end{array}$ & $\begin{array}{l}3.98 \\
4.00 \\
4.00 \\
4.32\end{array}$ & $\begin{array}{r}.36 \\
1.65 \\
1.33 \\
1.35\end{array}$ \\
\hline A verage........ & -.......... & 7. 70 & 4.00 & 1.17 \\
\hline $1935-36 \ldots \ldots .$. & 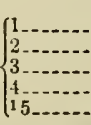 & $\begin{array}{r}3.40 \\
6.00 \\
7.25 \\
9.79 \\
10.82\end{array}$ & $\begin{array}{l}2.99 \\
4.29 \\
3.51 \\
4.00 \\
4.00\end{array}$ & $\begin{array}{r}.16 \\
.67 \\
1.17 \\
1.65 \\
2.41\end{array}$ \\
\hline A verage & - & 7.11 & 3. 72 & $1 . \overline{02}$ \\
\hline
\end{tabular}

1 15-day period.

BLACK, W. H., WARNER, K. F., and Wilson, C. V. See footnote 4. 
than did tnose in the second year's work and 39 pounds less than those in the third year, but they did not make a significantly greater gain than the calves in the two succeeding years. In the third year, however, the calves required a 15-day longer period to acquire a degree of finish believed to be comparable with that of the creep-fed calves (group 1A) in that year's test. As shown by table 7, the group 1B calves did not get on full feed during the third year so promptly as in preceding years and undoubtedly required a larger proportion of their feed for maintenance owing to the unfavorable weather, which was exceptionally severe during the third 28-day period in the winter of $1935-36$.

On the basis of average slaughter and carcass grades obtained in the 3-years' work, the calves in group 1B actually did not attain the degree of finish displayed by those in group 1A, which were graded low Choice. The former group most nearly approached the same degree of finish in the second year's experiment when it averaged high Good.

The return per calf in group $1 \mathrm{~B}$ after fattening in the dry lot was more uniform during the 3 years than that of any of the groups at time of weaning, as shown by a comparison with table 4 . The average return of the group $1 \mathrm{~B}$ calves, when fattened, was $\$ 1.83$ less than that of the same calves at weaning time and $\$ 0.88$ less than that of the group $1 \mathrm{~A}$ calves.

The average quantities and cost of the feed mixture and the hay consumed by the group 1B calves, for each 100 pounds of gain and per head during the entire feeding period, are shown in table 8. Notwithstanding the higher consumption of the mixture per head in the first year's experiment, the feed costs per head and per pound of gain were lower than in either of the other 2 years. The lower cost per head the first year was due mainly to the lower unit cost of feed at that time (table 1). The lower cost per 100 pounds of gain during the same year was also due to the slightly increased gain in weight.

TABLE 8.-Average quantities and cost of feed consumed by the group $1 B$ calves during the lot-fattening period

\begin{tabular}{|c|c|c|c|c|c|c|c|}
\hline \multirow{3}{*}{ Year of experiment } & \multirow{3}{*}{ Calves } & \multicolumn{4}{|c|}{ Feed consumed } & \multicolumn{2}{|c|}{ Feed cost } \\
\hline & & \multicolumn{2}{|c|}{ Per head } & \multicolumn{2}{|c|}{ Per 100 pounds gain } & \multirow{2}{*}{ Per head } & \multirow{2}{*}{$\begin{array}{l}\text { Per } 100 \\
\text { pounds } \\
\text { gain }\end{array}$} \\
\hline & & $\underset{\text { mixture }}{\text { Grain }}$ & $\begin{array}{c}\text { Alfalfa } \\
\text { hay }\end{array}$ & $\begin{array}{c}\text { Orain } \\
\text { mixture }\end{array}$ & $\begin{array}{l}\text { Alfalfa } \\
\text { hay }\end{array}$ & & \\
\hline $\begin{array}{l}1933-34- \\
1934-35 \\
1935-36\end{array}$ & $\begin{array}{r}\text { Number } \\
13 \\
9 \\
9\end{array}$ & $\begin{array}{r}\text { Pounds } \\
961 \\
863 \\
.903\end{array}$ & $\begin{array}{r}\text { Pounds } \\
373 \\
448 \\
\mathbf{4 7 4}\end{array}$ & $\begin{array}{r}\text { Pounds } \\
701.9 \\
657.3 \\
697.3\end{array}$ & $\begin{array}{r}\text { Pounds } \\
272.1 \\
341.1 \\
366.4\end{array}$ & $\begin{array}{r}\text { Dollars } \\
10.92 \\
21.73 \\
16.28\end{array}$ & $\begin{array}{r}\text { Dollars } \\
7.98 \\
16.47 \\
12.52\end{array}$ \\
\hline Average... & & 916 & 424 & 685.8 & 317.6 & 15.68 & 11.70 \\
\hline
\end{tabular}




\section{SUMMARY AND CONCLUSIONS}

Experiments were carried on for 3 years at the West Virginia Agricultural Experiment Station in which three groups of calves were handled as follows: The group 1A calves were creep-fed a mixture consisting of 8 parts of shelled corn and 1 part of cottonseed meal by weight while running with their dams on highly productive pasture. Those in group $1 \mathrm{~B}$ received no supplement while with their dams on highly productive pasture and, after being weaned, were fattened in the dry lot. The group 2 calves received no supplements while with their dams on mountain pasture. During the 168-day period previous to weaning, group $1 \mathrm{~A}$ gained 8.1 percent more than group $1 \mathrm{~B}$ and 25.3 percent more than group 2.

The creep-fed calves were fat enough to be classed as slaughter cattle when weaned and were marketed at an average age of 230 days, whereas the calves that received no supplement while on similar pasture with their dams were classed as feeders when weaned at 226 days of age.

An average of 2.65 pounds of supplement a head daily accounted for the difference in development at weaning time of the creep-fed calves over those not creep-fed.

An important point in the creep-feeding method of fattening calves for beef is the relatively small quantity of grain supplement required to produce 100 pounds of gain. An average of 123 pounds of grain was required for each 100 pounds of gain made by the creep-fed calves during the 3 years.

Calves in these experiments fattened by the creep-feeding method possessed sufficient finish to satisfy market requirements nearly 4 months sooner than the calves that received no supplement while on grass with their dams but that were fed, after weaning, alfalfa hay and a mixture of corn and cottonseed meal in the dry lot.

On the basis of the average slaughter and carcass grades for the 3 years, the group of calves fattened in the dry lot after weaning actually did not attain the degree of finish-low Choice-displayed by the creep-fed calves when they were marketed. The former group most nearly approached the same degree of finish in the second year's experiment, when the group average was high Good.

At weaning time in 1934 and 1935 , the return per calf in the group of feeders raised on highly productive land (group 1B) was larger than that of the fat weanlings (group 1A) and of the feeders raised on less fertile, rough mountainous land (group 2) and also when the 3 years' data are averaged. However, a marketing charge of $\$ 3.71$ per calf was deducted from the returns of the calves in group 1A, whereas such a deduction was not made from the returns of the other groups since they were not shipped to market at this time. If this charge had been deducted from the returns of the two feeder groups, the returns from group $1 \mathrm{~A}$ would have been the highest in all years.

The return per head of the group of calves fattened in the dry lot after weaning (group 1B) was more uniform during the 3 years than that of any of the groups at weaning. However, the average return per calf in group $1 \mathrm{~B}$, when fattened, was $\$ 1.83$ less than that from these calves at weaning time and $\$ 0.88$ less than that from the calves in group $1 \mathrm{~A}$. 

